\title{
Re-Visiting Political Corruption and Development in Nigeria under Democratic Rule
}

\author{
Dr Atelhe George Atelhe
}

Department of Political Science Ahmadu Bello University,Zaria

\section{Agada,Fakumo Timikoru}

Department of Political Science Federal University, Lafia

\section{Doi:10.5901/ajis.2014.v3n1p305}

\begin{abstract}
It has been observed that political corruption undermines development in all sectors of the economy in Nigeria. This paper attempts an overview of the relevance of anti-corruption to sustainable development in Nigeria. The position of this study is that the abuse of political power by those elected into various offices at all levels undermines Nigeria's endeavours towards development. This study thus examines the political economy of political corruption vis-à-vis human-wellbeing and development in Nigeria with emphasis on causes of corruption, relationship between corruption and underdevelopment, and proffers a broad schedule of recommendations. The study posits that there has been a state-centric advance to political corruption Nigeria, which hampers sustainable development in that context. Political corruption has usually been considered a threat to "national development". Thus, the study reviews extant government policies towards fighting corruption and suggests measures which are considered crucial for a more effective anti-corruption campaign.
\end{abstract}

Keywords: Corruption; Political Corruption; Development

\section{Introduction}

There are many troubling unresolved problems pertaining to political corruption in Nigeria. The damages political corruption has done to the polity are astronomical. Corruption in contemporary Nigeria has become a way of life. It has continued to keep its hold on the country. Diverse names have been used to tag it. Thus, phrases like "up front", "kick back", "PR", "Settlement" etc, are used/coined euphemisms to buttress bribery and political corruption. In offices, from the position of the clerk or messenger to the Director General, and up to every political position like the Presidency, corruption is a daily routine in Nigeria polity.

The menace of political corruption leads to slow movement of files in offices, police extortions at tollgates and slow traffic on the highways, port congestion, queues at passport offices and petrol stations, ghost workers syndrome, election irregularities, among others. Thus, it is believed by many in the society that political corruption is the bane of Nigeria. It brings about fundamentally distorted public policy, and governance, and adversely harms the poor masses. It further misdirects investable capital, and budgetary resources away from the provision of health, education and social amenities etc. Clearly corruption has eaten deep into the Nigerian public lives. At every level of public life, people and organizations dedicated to the advancement of democracy, social justice, poverty alleviation, conflict prevention, and international cooperation are agitating against political and bureaucratic corruption and as such the need for anti-corruption agencies to fight and curb corruption in Nigeria.

Like all dimensions of corruption, no itemization of its techniques can be complete and exhaustive because the perpetrators are always several steps ahead of the analyst in their capacity to evolve new techniques for their trade (Olopoenia, 1998: 19). But some types are identified:

i. Bribery, with its Nigeria variant of kick-backs;

ii. Nepotism;

iii. Misappropriation;

iv. The use of contrived security threats to the state or the larger society to obtain approval of extra-budgetary allocation for the personal enrichment of public officials charged with the maintenance of public order; 
v. The exploitation of privileged relationship with key public sector managers for the purpose of acquiring competitors business assets;

vi. Auto-corruption;

vii. Extortion; and

viii. Employment patronage.

However, all these variants of corruption can be generally found or located within the five species of graft, namely political corruption or corruption of greed, bureaucratic corruption, electoral corruption, embezzlement and bribery. Corruption is coined from the Latin word; coruptus which in essence means 'to destroy'. Corruption has broadly been defined as a perversion, or a change from good to bad. Specifically, corruption or corrupt behaviour involves the violation of established rules for personal gain and profit (Dike, 2008: 4). Corruption is efforts to secure wealth or power for private benefit (Lipset \& Lenz, 2000, 112-114).

This study attempts an overview of the relevance of anti-corruption to sustainable development in Nigeria. The position of this study is that the abuse of political power by those elected to various offices at all levels undermines Nigeria's endeavours towards development. This study thus examines the political economy of political corruption vis-àvis human-wellbeing and development in Nigeria with emphasis on causes of corruption, relationship between corruption and underdevelopment, and proffers a broad schedule of recommendations.

\section{Conceptual Clarifications}

A convenient starting point of any analysis will be the clarification of the concepts that will be used in the discourse. For this study, they include corruption; political corruption; and development.

\subsection{Corruption}

The Phenomenon of corruption now forms part of everyday discourse especially in a country like Nigeria, where the phenomenon is believed to be the major cause of underdevelopment. Despite the attention the phenomena has attracted, and the recognition of its manifestations by the public, and concept, like many others in the social sciences, has remained un-amenable to a comprehensive and all-embracing definition. This is so because the concept is used to describe a multitude of deviant behaviour and attempts to offer a precise definition have tended to confuse corruption with other related offences. Osoba (1996), for instance, defines corruption as any "anti-social behaviour conferring improper benefits contrary to legal and moral norms, and which undermines the authorities' capacity to secure the welfare of all citizens". From the above definitions, we could describe an act as corrupt when:

i. It involves an individual holding a position of authority, trust or responsibility, whether in the public or private sector and

ii. The act committed contravenes any rule, law or regulation, including existing norms and values of a community or an institution

iii. It is done intentionally to advance narrow private interests and or objectives.

This vividly explains the present Nigerian dilemma where governance is carried out without respect to the wishes and aspiration of the people etc.

\subsection{Political Corruption}

Political corruption takes place within the domain of political authority. It occurs when the politicians and political decisionmakers, who are entitled to formulate, establish and implement the laws in the name of the people, are themselves corrupt. It also takes place when policy formulation and legislation is tailored to benefit politicians and legislators. Political corruption is sometimes seen as similar to corruption of greed as it affects the manner in which decisions are made; it also manipulates political institutions, rules of procedure, and distorts the institutions of government (NORAD. ch.4, Jan. 2000: the Encyclopaedia Americana, 1999).

\subsection{Development}

Development in human society is multi-facet process. It had been quite similar to the older concept of "progress" or advancement and there has been some effort to give the concept a precision. To a large extent the literature on 
development shows that it is a nebulous concept. Given this, diverse models or paradigms have emerged to explain what it means. Thus, several definitions have been advanced to make the concept clearer. In this regard, some scholars equate growth development, and see it in terms of an increase in total per capita income or output. Others prefer to identify structural changes as a major component of development, arguing that growth (increase in output) must be accompanied with structural changes-reduction in poverty, inequality, unemployment, access to basic social amenities, etc. (Nye 1967).

\section{Forms of Political Corruption}

- Bribery: The payment (in money or kind) that is taken or given in a corrupt relationship. These include kickbacks, gratuities, pay-off, sweeteners greasing palms, etc (Bayart et. Al 1997, p.11).

- Fraud: It involves some kind of trickery, swindle and deceit, counterfeiting, racketing, smuggling and forgery (lbid. p.11).

- Embezzlement: This is theft of public resources by public officials. It is when a state official steals from the public institution in which he/she is employed. In Nigeria the embezzlement of public funds is one of the most common ways of economic accumulation, perhaps, due to lack of strict regulatory systems.

- Extortion: This is Money and other resources extracted by the use of coercion, violence or threats to use force. It is often seen as extraction from below (The police and custom officers are the main culprits in Nigeria) (Bayart et. al 1997, p.11).

- Favouritism: This is a mechanism of power abuse implying a highly biased distribution of state resources. However, this is seen as a natural human proclivity to favour friends, family and anybody close and trusted.

- Nepotism: This is a special form of favouritism in which an office holder prefers his/her kinfolk and family members. Nepotism, (which is also common in Nigeria), occurs when one is exempted from the application of certain laws or regulations or given undue preference in the allocation of scarce resources (NORAD, ch.1, ch. 2 \& ch.4, Jan. 2000; Amundsen, 1997 Girling 1997; also see Fairbanks, Jr. 1999).

\section{Incidence and Prevalence of Corruption in Nigeria}

The prevalence of corruption especially in the public domain, is a cancer worm eaten deep into the very fabrics of our nation (Nigeria); and the apparent intractability and endemic situation adversely affect the present and the future of Nigeria is at stake; hence, the relevance of anti-corruption serves as a panacea to sustainable development in Nigeria. Since 1996, international anti-corruption agreements have served to heighten political commitments to fight corruption have identified fundamental international norms and practices for addressing corruption. Fighting corruption was once thought to be the domain of each government. Due in part to anti-corruption agreements, reinforced by the growing statements of political will, it is now universally accepted by the international community to complement and assist a government's effort to fight corruption, and that the international community has a genuine interest in seeing corruption addressed locally and on global scale.

Corruption in Nigeria has been traced to the rise of public administration. The introduction of western education, urbanization, monetized economy, formal international trade and exchanges during this period in no small ways contributed to the growth of individualism which led to the rise of corruption. In addition, the Indirect Rule system in Southern Nigeria brought with it incidences of public office corruption. Considering the influence and power these chiefs wielded, all kinds of tricks and activities were exploited to secure and keep such appointments. Many of the appointed people were of questionable character who often became intoxicated by power, leading them to abuse and misuse of office. In 1919 and in 1930, reports submitted by the Secretary of Native Affairs found that applicants merely sought warrants for self-enrichments and profligacy. The same act of corruption was reported of court clerks and messengers.

The nationalists who took over the government from the colonialists before full independence was attained were not free acts of corruption. For instance, the Foster-Sutton Commission of Inquiry set up to look into the management of the African Continental Bank owned by the Eastern Region government in the mid-1950s found that the bank had been strengthened by the addition of two million pounds of public funds by Dr. Nnamdi Azikwe. In the Post Colonial era, the Coker Commission of Inquiry in the early 1960s also found the activities of some Western Region Government Corporation as tainted by corrupt practices. The Federal government and regional levels during the First Republic (19601966) were also corrupt as they were characterized by electoral corruption and malpractices involving the use of money to buy votes, employment of thugs to intimidate political opponents, hiring of assassins to eliminate opponents, hijacking 
of electoral boxes and materials, and the printing of fake voting cards, etc.

The military regimes (1966-1979; 1983-1998) tended to be more corrupt than the regimes they claimed to have come to correct. Despotism, which inevitably characterizes military regimes, destroyed a culture of accountability and institution of programmes such as WAIC (War Against Indiscipline and Corruption) and MAMSER (Mass Mobilization Socio-Economic Reconstruction) to check corruption were more of window dressing as these programmes were shortlived and largely ineffectual because there was no sincerity behind their introduction as seen from the sudden inexplicable acquisition of wealth by serving military officers and their cronies. The record of General Sani Abacha loot alone was put at between \$5-6 Billion dollars while the issue of disappearance of \$12-4 Billion dollars Gulf War oil windfall under General Ibrahim Babangida remains an unresolved mystery. It is common knowledge today that million regimes institutionalized corruption and corrupt practices and enthroned a culture of graft (Owolabi 2007).

The civilian administration of 1979-1983 was also characterized by lack of accountability, electoral fraud, violence and kick-backs. When Chief Olusegun Obasanjo assumed office on May 1999, he made it clear from the outset that the government was determined to fight corruption and to this end he put in place two anti-graft bodies to deal with the problem. Despite this effort, corruption continues to thrive with the country ranking as one of the most corrupt countries in the world.

\subsection{Transparency International Corruption Perception Index (CPI) Report}

Corruption is a global ethical and legal issue and is defined by Transparency International as the abuse of entrusted power for private gain. The aim of the Global Corruption Report is to bring the matter of corruption to the attention of the world and aid in combating it. It is also designed as a tool to help policy makers and the public to change corrupt behaviour by providing guidelines and recommendations within the report. The Global Corruption Report uses various sources of information including experts and activities, as well as up to date research, in order to bring to the fore the recent developments in corruption. The report also addresses international and regional trends, highlights significant cases and uses the Bribe Payers Index and the Corruption Perceptions Index as empirical evidence of corruption. The report provides an assessment of corruption within more than 30 countries, as well as research findings and perspectives, and it is designed to be useful to a broad range of readers. This includes policy makers, journalists, educators, as well as the general public.

In 1996 Study of Corruption by Transparency International and Goettingen University ranked Nigeria as the most corrupt nation, among 54 nations listed in the study, with Pakistan as the second highest (Moore 1997, p.4). As this was not too bad enough, the 1998 Transparency International Corruption Perception Index (CPI) of 85 countries, Nigeria was 81 out of 85 countries pooled (Table A); (Lipset \& Lenz 2000; p.113). Also in the 2001 corruption perception index (CPI), the image of Nigeria slipped further down south (ranked 90, out of 91 countries pooled), with second position as most corruption nation, with Bangledesh coming first (Table B).

Table B: Corruption Perception Index (The top 10 countries)

\begin{tabular}{|l|c|l|c|l|c|}
\hline \multicolumn{1}{|c|}{ Country } & Rank & \multicolumn{1}{c|}{ Country } & Rank & \multicolumn{1}{c|}{ Country } & Rank \\
\hline Denmark & 1 & Finland & 1 & Finland & 1 \\
\hline Finland & 2 & Denmark & 2 & Iceland & 2 \\
\hline Sweden & 3 & New Zealand & 3 & Denmark & 3 \\
\hline New Zealand & 4 & Iceland & 4 & New Zealand & 4 \\
\hline Iceland & 5 & Singapore & 5 & Singapore & 5 \\
\hline Canada & 6 & Sweden & 6 & Sweden & 6 \\
\hline Singapore & 7 & Canada & 7 & Netherland & 7 \\
\hline Netherland & 8 & Netherland & 8 & Australia & 8 \\
\hline Norway & 9 & Luxembourg & 9 & Norway & 9 \\
\hline Switzerland & 10 & Norway & 10 & Switzerland & 10 \\
\hline
\end{tabular}


Table B: Corruption Perception Index (The bottom 10 countries)

\begin{tabular}{|l|l|l|l|l|l|}
\hline Vietnam & 75 & Russia & 81 & Angola & 124 \\
\hline Russia & 76 & Tanzania & 82 & Azerbaijan & 125 \\
\hline Ecuador & 77 & Ukraine & 83 & Cameroon & 126 \\
\hline Venezuela & 78 & Azerbaijan & 84 & Georgia & 127 \\
\hline Colombia & 79 & Bolivia & 85 & Tajikistan & 128 \\
\hline Indonesia & 80 & Cameroon & 86 & Myamar & 129 \\
\hline Nigeria & 81 & Kenya & 87 & Paraguay & 130 \\
\hline Tanzania & 82 & Indonesia & 88 & Haita & 131 \\
\hline Honduras & 83 & Uganda & 89 & Nigeria & 132 \\
\hline Paraguay & 84 & Nigeria & 90 & Bangledesh & 133 \\
\hline
\end{tabular}

\section{Source (s):}

i. The Transparency International Corruption Index, 1998, and

ii. Lipset, Seymour and Salman Lenz, ("Corruption, Culture and Marxist," 2000), in Culture Matters, Harrission and Huntington (eds.), 2000, p.113

iii. The Transparency International Corruption Index, 2001; pp.234-236

iv. Worldwide Corruption Perception Ranking of Countries Published by Transparency International, According to the Global Corruption Perception Index (CPI) 2009/2010 by Transparency International (TI), a global anticorruption watchdog; Nigeria takes $130^{\text {th }}$ position out of the 180 countries.

Global perception of the anti-corruption battle in Nigeria got a modicum of approval, after the global anti-corruption body, Transparency International, TI, moved the country four places up in its yearly ranking of public sector transparency. Nigeria's 139 ranking was up from the 143rd position the country was ranked last year, according to the TI ranking released early yesterday.

In summary, corruption diverts scarce public resource into private pockets, literally undermines effective governance, development, endangers democracy and erodes the social and moral fabric of nations. As it has been noted the lust for power and corruption (and dash) as gift known in Nigeria, is not strictly not a Nigerian problem. Corruption is a global phenomenon and manifest in both petty and grand forms.

\section{Causes of Corruption in Nigeria}

The causes of corruption are myriad; and they have political and cultural variables. Some evidence points to a link between corruption and social diversity, ethno-linguistic fractionalization, and the proportions of country's population adhering to different religious traditions (Lipset and Lenz, 2000). Studies note also that corruption is widespread in most non-democratic countries, and particularly, in countries that have been branded neo-patrimonial, kleptocratic and prebendal (NORAD 2000). Thus, the political system and the culture of a society could make the citizens more prone to corrupt activities. However, we shall focus on the fundamental factors that engender corrupt practices in Nigeria. Some of the factors include:

i. Great inequality in distribution of wealth;

ii. Political office as the primary means of gaining access to wealth;

iii. Conflict between changing moral codes;

iv. The weakness of social and governmental enforcement mechanisms; and

v. The absence of strong sense of national community (Bryce, 1921)

In Nigeria, the civil service employees view public service as an opportunity for self enrichment; hence incompetence and inefficiency among the public servants have been given as one of the causes of corruption. Pervasive and chronic poverty, extremely high levels of material deprivation; severe deprivation and severe inequalities in the distribution of resources have been advanced as major determinants of corruption in Nigeria (Osoba, 2000, 473; Arowolo 2004, 64). The emergence of the military in the political decolonization of Nigeria, as an important force in the allocation of resources has further distorted income distribution and elevated corruption. Also, contributory is the weak foundation upon which the Nigerian state is built. The state actors capitalize on the 'softness' of the state to enrich themselves at the expense of political and socio-economic development of the country.

Nigeria's Economic and Finance Crime Commission (EFCC), Independent and Corrupt Practices Commission (ICPC) are leading the drive against corruption in Nigeria. But just how serious are these investigative bodies and 
commissions on corruption? The former head of the Economic Finance and Crime Commission (EFCC) Nuhu Ribadu, was lauded internationally as a beacon of hope in Africa's fight against corruption when he recovered billions of dollars in stolen public funds and successfully prosecuted scores of international fraudsters and to government officials.

According to a report in Nigeria's (Guardian newspaper in June 11, 2000) "Corruption has taught the Nigerian a dangerous and wrong lesson that it does not pay to be honest, hardworking and law-abiding". Through corrupt means many political office holders acquire wealth and properties in and outside Nigeria; and many display their wealth (which is beyond the means), but the society does not blink. This has made politics a bid business in Nigeria, because anything spent to secure a political office is regarded as an investment, which matures immediately one gets into office. The brazen display of wealth by public officials which, they are unable to explain the source... point to how bad corruption has reached in the society. Many of these officials before being elected or appointed into offices had little or modest income, but now, they are owners of many properties around the world (ThisDay Online, June 24, 2002).

All these, including bad practices of non-payment or late payment of workers, bad business culture of delays and refusal, or late payment of services executed by business establishments in Nigeria are forms of corruption. These kinds of behaviours have the tendency to scare way foreign and local investors, with tremendous negative effects on the economy (Daily Trust, July 9, 2002).

\section{Effect of Corruption on Development in Nigeria}

Political corruption is an issue that is at the fore-front of national discourse. The concept 'corruption' is one of the most fundamental causes of underdevelopment in Nigeria. Writers have written a lot on corruption and development, e.g. the effects of corruption on a nation's socio-political and economic development are myriad. Its negative impacts effect growth as it, among other things, reduces public spending on education (Mauro 1997; and 1995). Lipset and Lenz note that the effect on growth is in part, a result of reduced level of investment, as it adds to investment risk (2000). The effect of corruption on education comes from the fact that the government spends relatively more on items to make room for graft (Shleifer and Vishny, 1993; Lipset and Lenz, 20002). And corrupt government officials would shift government expenditures to areas in which they can collect bribes easily. Large and hard-to-manage projects, such as airports or highways, make fraud easy. In addition, poverty and income inequalities are tied to corruption (Lipset and Lenz 2000). Development projects are often made unnecessarily complex in Nigeria to justify the corruption and huge expenses on it. The new national stadium in Abuja, which is said to have gulped millions of Naira more than necessary, is a case in point. This also explains why the Goodluck Jonathan administration has made the fight against corruption a priority.

Corruption is not new in Nigeria, and since it is a global phenomenon, it is not unusual to Nigeria. If there is a lack of control of corruption in every sphere in the nation, it is then like the old saying: when water chokes you, what do you take to wash it down? (The Philosophy of Aristotle, 451-ME2783, p.355). Corruption is endemic in all governments, and it is not peculiar to any continent, region and ethnic group. Corrupt practices did not begin today; its history is as old as the world. Ancient civilizations have traces of widespread illegality and corruption. Thus, corruption has been ubiquitous in complex societies from ancient Egypt, Israel, Rome, and Greece down to the present (Lipset and Lenz 2000, pp.112113).

Corruption has been around for over decades, the recent development in Nigeria where discoveries of stolen public funds run into billions of US Dollars and Nigeria Naira, make these observations adequate and appropriate. Corruption is probably the main means to accumulate quick wealth in Nigeria. Corruption occurs in many forms, and it has contributed immensely to the poverty and misery of a large segment of the Nigerian population. Also, a vast emerging evidence of corruption by public officers over the years especially in the Babangida regime who smuggled on expensive car into the country in a container declared as containing essential food items without paying the necessary excise duties. The Punch in its editorial, on March 8, 1999, discovered that corruption is one of the greatest challenges of the world.

Corruption wastes skills as precious time is often wasted to set up unending committees to fight corruption, and to monitor public projects. It also leads to aid forgone. Some foreign donors do not give aid to corrupt nations. For instance, the International Monetary Fund (IMF) has withdrawn development support from some nations that are notoriously corrupt. And the World Bank has introduced tougher anti-corruption standard into its lending policies to corrupt countries. Similarly, other organizations such as the Council of Europe and the Organization of American States are taking tough measures against international corruption (OECD, December 1997).

Corruption causes a reduction in quality of goods and services available to the public, as some companies could cut corners to increase profit margins. Corruption effects investments, economic growth, and government expenditure 
choices; it also reduces private investment (Mauro 1997). Corruption is politically destabilizing, as it leads to social revolution and military takeovers. Most "post-coup rationalizations" in less developed worlds point to corruption. The General Buhari's post-coup broadcast to Nigerian in 1983 is a case in point (Welch, Jr., 1987). By hiding under the excuse of corruption to topple a legitimate government in Nigeria will seize to be a credible reason for the involvement of the military in Nigerian politics in future. This is because many of the previous military leaders in Nigeria were as corrupt, if not more corrupt than the civilian politicians they replaced. Corruption was even blamed for the first 1966 military coup in Nigeria. However, the post-electoral crisis in the Western Region and the fear of Northern domination of the affairs of Nigeria were other reasons (Wallerstein, March 14, 1966; \& Kilson, Jan 31, 1966).

\section{Conclusion and Recommendations}

\subsection{Conclusion}

One of the authors whose work we reviewed noted, that one of the reason why the measures against corruption have not been fruitful in Nigeria is that they have operated at a level (of mere) symbolism (Osoba 1996). Corruption has defied all measure adopted to combat it in Nigeria, apparently, because those waging the corruption wars are themselves corrupt. In the name of turning Nigeria into a corruption-free society, the nation has experimented with many policies. It has tried the Judicial Commissions of Inquiry; the Code of Conduct Bureau, it had also wrestled with the Public Complaints Commission to no avail. Furthermore, with the defunct Mass Mobilization for Social Justice and Economic Recovery (MAMSER), and the National Open Apprenticeship (NOA), but corruption instead blossomed. Then, General Buhari clobbered Nigerians with his horsewhip branded the War Against Indiscipline Council (WAIC), without success. Also, the civilian administration of President Olusegun Obasanjo has instituted an Independent Corrupt Practices Commission (ICPC), which seems to have power only over the corrupt poor, now the Economic Crime and Financial Commission (EFCC).

However, while the Justice Oputa Panel and the Justice Akambi commissions were interrogating the poor corrupt individuals involved in petty thefts, the politicians and the known ex-military Generals have been busy politicking around the nation with money stuffed in their Ghana-must to (bag) unperturbed. But to win the apparent war on corruption in Nigeria, the Obasanjo's slogan of "there must be no sacred cows should not be a mere political rhetoric". It should be put into practice by prosecuting all the known corrupt political heavy weights in the society, as they contribute in making the nations inchoate laws inoperable. As Kanu Agabi, the Attorney General and Minister of Justice noted at a meeting with state commissioners police:

Some of our leaders are doing everything they can to make the work of the police impossible. Big men are the greatest criminals and except you go after the big criminals and bring them to book, the rate of crime may not reduce. (But if you bring three or four of these big men to book, the rate of criminal activities would reduce. He declared, Arrest ministers, arrest (the) big people and others would fear (The Vanguard, 30th March, 2002).

Nigeria have for long been living on the survival of the fittest and grab-whatever-comes-your-way mentality (Dike, October 6, 1999; Dike, February 5, 2002). The re-orientation of the youth in Nigeria to a good value system could help in the war against corruption. The World Values Survey of 1990-1993 has a lot of attitudes and values information, which notes a relationship between values and corruption (World Values Study Group, 1994). Preaching the gospel and practice of virtue is the ultimate solution to behavioural change and reduction in corruption. This implies that enough goods and services, prosperity and economic growth, and which would in turn allow the citizens the freedoms to live a meaningful life.

The keys to effectively managing corruption in any society are honesty and integrity, effective leadership and governance, transparency and accountability, because corrupt leaders cannot wage effective war against corruption. It is appropriate to emphasize the important good and enforceable policies toward controlling corrupt behaviour. And policies should be reviewed periodically to close any loophole and to catch-up with events in the society. Robert S. McNamara, former president of the World Bank and Ford Motor Corporation, argued that for any campaign against corruption to be successful in Sub-Saharan Africa, certain characteristics should be common in the plans against corruption. His suggestions on how to control corruption in the region include to:

i. Require direct, clear and forceful support of the highest political authority: the president and prime minister;

ii. Introduce transparency and accountability in government functions, particularly in all financial transactions;

iii. Encourage a free press and electronic media to forcefully report to the public on corrupt practices in the 
society;

iv. Organize civil society to address the problem of corruption brought to light by the process of transparency and the activity of the media;

v. Introduce into government watch-dog agencies - anti-corruption bureaus; inspectors general; auditor-general and ombudsmen (government official appointed to receive and investigate complaints made by individuals against abuses or capricious acts of public officials, etc), which will identity corrupt practices and bring them to public attention;

vi. Minimize government regulations, particularly those involving the issuance of licenses, permits and preferential positions, thereby restricting opportunities for rent-seeking by corrupt means;

vii. Insert anti-bribery clauses into all major procurement contracts and with the assistance of both international financial institutions and bilateral and agencies insist that international corporation, bidding on African procurement contracts, accept such clauses and the penalties associated with their violation;

viii. Introduce similar anti-corruption clauses into contracts relating to privatization of government enterprises, and the development of natural resources;

ix. Ensure that enforcement is predictable and forceful; and

$x$. To criminalize the acts of bribery; prohibit the deduction of bribes for tax purposes; and erect barriers to transfer to western financial institutions of financial gains derived from corrupt practices (United States Information Agency, Nov 17, 1997).

Essentially therefore, corruption can be said to have been institutionalized in Nigeria and is created and fuelled by the dominant political elite in the society which ensures that the masses remain at once poor and neglected and therefore malleable to underdevelopment and political manipulation. As Alagoa similarly noted, "The lower class, though instruments of the ruling class, are themselves recipients of institutionalized deprivation and dehumanization which also deny them of the capability to accord respect and dignity to other human beings beside the rulers" (Alagoa, 1997).

\subsection{Recommendations}

Corruption is a social virus which must be tamed if development is to thrive. Therefore, is worthy of mention some strategies that would be employed in fighting it. All forms of corruption, including its open and secret manifestations like bribery, over-invoicing, advance fee fraud, (known in Nigeria idiom as 419), election rigging and falsification of voters' registers, money laundering, examination malpractices, embezzlement of or late payment of workers' salary, have different reason why they occur, even though central to them are institutional or structural and not decadence of value system.

For corruption to be curbed and development to be engendered in Nigeria, the following options would need to be explored and employed:

i. Corruption must be identified as a factor in national development of Nigeria and must be uprooted with bottomtop strategies which must involve the entire sundry.

ii. Campaign against corruption must be simple to understand, even by the starkest of the unlettered.

iii. Poverty must be fought head-on. No campaign against corruption would sell when the majority of the population lives in abject poverty. Avenues for job creation and micro-credit schemes must be found, if the vicious circle of poverty is to be ended.

iv. The government, at the state level, must always listen to the people. Corruption will thrive amongst a population whose leaders do not listen. Deliberately, deaf government tends to be bad, inept and corrupt as well.

v. The government must always have a change of heart in the way and manner it conducts itself and its affairs, especially when such affairs are anti-people. Since reforms should be embarked upon in order to chart a new course for the public service delivery and transparent and good governance.

vi. As contained in the National Economic empowerment and Development Strategies (NEEDS) documents empowering the people will help spell a death knell for corruption and sound a note of readiness for maximization of Nigeria's development potentials. This can be done by improving he people's health, education, environment, integrate rural development, housing and employment. This can further be achieved via youth development, provision of safety nets, gender and geo-political balance, and pro-people pension reforms.

vii. The media have critical roles to play in curbing corruption by monitoring and exposing it. In other words, 
checks on government decisions, discretions, and direction must come from outside official circles as well. The open exchange of ideas and information has always been the cornerstone of freedom. This is necessary if economic dynamism and survival is to be achieved. In other words, an informed citizenry is needed to make demands on government to come up with improved politics and corruption-free institutions. A recurring lesion from economies dealing with financial turbulence is that full disclosure of financial information, good or bad, is fundamental for stable economic growth. The media are the most dynamic guarantee of this kind of information.

viii. Fighting corruption is not an isolated goal. International bodies like United Nations, African Union, and ECOWAS must help nations and states more prone or vulnerable to corruption towards eradicating the menace.

Therefore, corruption impedes development, and efforts to eradicate it are on-going, in Nigeria; yet much still has to be done. The fight against corruption must not be selective; it must not necessarily be a means of political end. Leaders must lead by example; followers must follow with sincerity; and the struggle to rescue Nigeria from further drift into abyss is a task that must be done quickly. The individuals must begin to see their public realm as they see their private realm. After all, the public life is the amalgam of many private lives. The former is also the decider of the fate of the latter.

It is high time that people should begin to think and act in terms of 'we' rather than in terms of 'l', and considerable bottom-top efforts should be made to transfer the 'morality' and loyalty of the primordial public to the civic public. It is only by doing all this that the Nigerian system, whose subsystems or institutions are already becoming increasingly rotten, will be rescued from the jaw of the crocodile called corruption, which dangles the state in and out of the sea of development preparing to swallow it into it.

\section{References}

Alatas, Syed Hessein, The Sociology of Corruption Singapore, Times Book, 1980

Dickson Agedah, Corruption and the Stability of the Third Republic (1993)

Dike, Victor E., The Philosophy of Transforming Nigeria into a Corruption-free Society: are the probes the Solution? Online Publication. Nigeriaworld.com/feature/article/corruption.html, October 6, 1999

Larry Diamond (2004) "Building A System of Comprehensive Accountability to Control Corruption". In Adigun Agbeje, Larry Diamond and Ebere Onwudiwe, (eds), "Nigeria's Struggle for Democracy and Good Governance". A Festschrift for Oyeleye Oyediuran, Ibadan: Ibadan University Press, 221 - 242.

Lipset, Seymour Martin, and Gabriel Salman Lenz, Corruption, Culture and Markets, in Culture Matters, Lawrence E. Harrison, and Samuel P. Huntington, eds, (New York; Basic) available at www.ueforic.org/courier/158e fri.htm

Madueke, Ojo, Corruption and The Nigeria Project-Issues, ThisDay Sunday Online, May 26, 2002

Michael Johnson, Victor T. LeVine, and Arnold heidenheimer, eds. (1970) Political Corruption: Readings in Comparative Analysis

Nye, J. S., Corruption and Political Development: A Case-Benefit Analysis The American Political Science Review, 1967, pp.417-427, available at unan1.un.org/intradoc/groups/public/.../UNPAN0005333.pdf

See the Role of Bilateral Donors in Fighting Corruption, April 22-27, 2000, Maastricht, Published in book form in 2001; edited by Lara M. Gabriel and Rick Staphenhurst, with Mary Thomas, courtesy the International Bank for Reconstructing and Development, IBRD. The book features the background papers, discussions, and the recommendations from the Maastricht Conference and Ustein group's Statement. The Ustein Group, it is to be noted refers to a group of four (female) Ministers for Development and Cooperation of the Netherlands, Germany, Norway, and the United Kingdom, which met on 25 and 26 June, 1999 on how to join forces an intensity their cooperation on a number of issues. One of the issues Ustein Minister decided to tackle jointly was the fight against corruption. Herfken's speech was titled "Corruption Distorts Development Investment".

S. Southgate, "Political Corruption in E.PA Seligman (ed) Encyclopedia of Social Sciences, Vol.131987 p.17

Treisman, Daniel, The Causes of Corruption: A Cross-National Study (1998), pp.22-23; accessed at www.unu.edu/millennium/weder.pdf

Victor E. Dike, (2005), Corruption in Nigeria: A New Paradigm for Effective Control http:// www.africaeconomicanalysis.org1 articles/gem/corruptiondikehtm.html, visited 1/05/2013

Zwingina, J.A. (1999), "Capitalist Development in an African Economy", Ibadan, Ibadan: University Press. 
